\title{
Radioactive Iodine and Krypton Control for Nuclear Fuel Reprocessing Facilities
}

\author{
Nick R. Soelberg, ${ }^{1}$ Troy G. Garn, ${ }^{1}$ Mitchell R. Greenhalgh, ${ }^{1}$ Jack D. Law, ${ }^{1}$ Robert Jubin, \\ Denis M. Strachan, ${ }^{3}$ and Praveen K. Thallapally ${ }^{3}$ \\ ${ }^{1}$ Idaho National Laboratory, Idaho Falls, ID 83415, USA \\ ${ }^{2}$ Oak Ridge National Laboratory, Oak Ridge, TN 37831, USA \\ ${ }^{3}$ Pacific Northwest National Laboratory, Richland, WA 99252, USA \\ Correspondence should be addressed to Nick R. Soelberg; nick.soelberg@inl.gov
}

Received 4 March 2013; Accepted 22 July 2013

Academic Editor: Candido Pereira

Copyright (C) 2013 Nick R. Soelberg et al. This is an open access article distributed under the Creative Commons Attribution License, which permits unrestricted use, distribution, and reproduction in any medium, provided the original work is properly cited.

\begin{abstract}
The removal of volatile radionuclides generated during used nuclear fuel reprocessing in the US is almost certain to be necessary for the licensing of a reprocessing facility in the US. Various control technologies have been developed, tested, or used over the past 50 years for control of volatile radionuclide emissions from used fuel reprocessing plants. The US DOE has sponsored, since 2009, an Off-gas Sigma Team to perform research and development focused on the most pressing volatile radionuclide control and immobilization problems. In this paper, we focus on the control requirements and methodologies for ${ }^{85} \mathrm{Kr}$ and ${ }^{129} \mathrm{I}$. Numerous candidate technologies have been studied and developed at laboratory and pilot-plant scales in an effort to meet the need for high iodine control efficiency and to advance alternatives to cryogenic separations for krypton control. Several of these show promising results. Iodine decontamination factors as high as $10^{5}$, iodine loading capacities, and other adsorption parameters including adsorption rates have been demonstrated under some conditions for both silver zeolite (AgZ) and Ag-functionalized aerogel. Sorbents, including an engineered form of $\mathrm{AgZ}$ and selected metal organic framework materials (MOFs), have been successfully demonstrated to capture $\mathrm{Kr}$ and Xe without the need for separations at cryogenic temperatures.
\end{abstract}

\section{Introduction}

Nuclear fission results in fission products and activation products, some of which are volatile under the conditions of used nuclear fuel (UNF) reprocessing. The radionuclides that have been identified as "volatile radionuclides" are noble gases (most notably isotopes of $\mathrm{Kr}$ and $\mathrm{Xe}$ ) $,{ }^{3} \mathrm{H},{ }^{14} \mathrm{C}$, and ${ }^{129} \mathrm{I}$.

Radionuclides that tend to form volatile species evolve into reprocessing facility off-gas systems and are more challenging to be efficiently controlled compared to radionuclides that remain with the solids or liquids during fuel reprocessing. Unless otherwise managed, these radionuclides would be released to the environment. It is nearly certain that for any future used nuclear fuel (UNF) reprocessing facilities to meet licensing requirements in the United States, efficient capture of some volatile radionuclides from the plant off-gas streams will be needed.
In aqueous reprocessing, these radionuclides are most commonly expected to evolve into off-gas streams as tritiated water $\left({ }^{3} \mathrm{HHO}\right.$ or $\left.{ }^{3} \mathrm{H}_{2} \mathrm{O}\right)$, radioactive $\mathrm{CO}_{2}\left({ }^{14} \mathrm{CO}_{2}\right)$, noble gases (mainly ${ }^{85} \mathrm{Kr}$ ), and iodine $\left(\mathrm{H}^{129} \mathrm{I},{ }^{129} \mathrm{I}_{2}\right.$, or organic iodides). The fate and speciation of these radionuclides from a nonaqueous fuel reprocessing facility are less well known at this time, especially with respect to organoiodide species, but active investigations are in progress.

An Off-Gas Sigma Team was formed in late fiscal year (FY) 2009 to integrate and coordinate the Department of Energy (DOE) Fuel Cycle Research and Development (FCR\&D) activities directed towards the capture and sequestration of the these volatile radionuclides [1]. The Sigma Team concept was instituted in an effort to bring together multidisciplinary teams from across the DOE complex that would work collaboratively to solve the technical challenges and to develop the scientific basis for the capture and 
immobilization technologies. The laboratories currently participating in this effort are Idaho National Laboratory (INL), Oak Ridge National Laboratory (ORNL), Pacific Northwest National Laboratory (PNNL), and Sandia National Laboratories (SNL).

In this paper, we focus on the control of ${ }^{129} \mathrm{I}$ and ${ }^{85} \mathrm{Kr}$ emissions from aqueous reprocessing of UNF. Most of the work by the Off-gas Sigma Team has focused primarily on the capture and sequestration of ${ }^{129} \mathrm{I},{ }^{85} \mathrm{Kr}$, and ${ }^{3} \mathrm{H}$, mainly because, as discussed below, control of ${ }^{129} \mathrm{I}$ can require high efficiencies to meet regulatory requirements; removal of ${ }^{85} \mathrm{Kr}$ with a cryogenic process, which has been the technology demonstrated to date, can add considerably to the construction and operating costs of a reprocessing facility; and tritium capture, while in theory relatively simple, is in practice quite complicated owing to the problems associated with its evolution prior the fuel dissolver, dilution with process water (liquid and vapor), and coadsorption with other species.

\section{Regulatory Requirements for Iodine and Krypton Capture}

Volatile radionuclide emissions from a nuclear fuel recycle facility are addressed in several regulations as summarized in Table 1.

\subsection{The US Code of Federal Regulations (CFR) Title 40,} Part 190: Environmental Radiation Protection Standards for Nuclear Power Operations. The United States (US) Environmental Protection Agency (EPA) has established, through 40 CFR 190 [2], annual dose limits for nuclear fuel cycle facilities in the commercial sector. In 40 CFR 190.10(a), dose limits to any member of the public are specified $(25 \mathrm{mrem} / \mathrm{y}$ $(0.25 \mathrm{mSv} / \mathrm{y})$ to the whole body, $75 \mathrm{mrem} / \mathrm{y}(0.75 \mathrm{mSv} / \mathrm{y})$ to the thyroid, and $25 \mathrm{mrem} / \mathrm{y}(0.25 \mathrm{mSv} / \mathrm{y}))$ as a result of planned discharges of radioactive materials. Also in 40 CFR 190.10(b), release limits are specified for ${ }^{85} \mathrm{Kr}$, ${ }^{129} \mathrm{I}$, and ${ }^{239} \mathrm{Pu}$ and other alpha-emitting transuranic radionuclides with half-lives greater than one year in curies $(\mathrm{Ci})$ released per gigawatt-year (GWy) of electric power produced (50 000 $\mathrm{Ci}\left(1.85 \times 10^{6} \mathrm{GBq}\right)$ of ${ }^{85} \mathrm{Kr}, 5 \mathrm{mCi}(0.185 \mathrm{GBq})$ of ${ }^{129} \mathrm{I}$, and $0.5 \mathrm{mCi}(0.0185 \mathrm{GBq})$ composed of ${ }^{239} \mathrm{Pu}$ and other alphaemitting transuranic radionuclides with half-lives greater than one year).

According to 40 CFR 190, emissions of both ${ }^{129} \mathrm{I}$ and ${ }^{85} \mathrm{Kr}$ need to be limited to meet the lower value of (a) their specific fuel-cycle-based emission limit and (b) the value needed to limit the combined dose equivalent (from all radioactive material discharges) to any member of the public.

\subsection{CFR 20: Standards for Protection against Radiation.} The US Nuclear Regulatory Commission (NRC) provides dose limits from facilities licensed by the NRC for workers and individual members of the public in 10 CFR 20 [3].

Section 10 CFR 20.1101(b) states that "the licensee shall use, to the extent practicable, procedures and engineering controls based upon sound radiation protection principles to achieve occupational doses and doses to members of the public that are as low as is reasonably achievable (ALARA)." Section 10 CFR 20.1301 specifies dose limits for individual members of the public $(0.1 \mathrm{rem}(1 \mathrm{mSv})$ per year and $0.002 \mathrm{rem}(0.02 \mathrm{mSv})$ in any one hour). This section also states that "a licensee subject to the provisions of EPA's generally applicable environmental radiation standards in 40 CFR Part 190 shall comply with those standards."

Section 10 CFR 20.1302 describes how to comply with the dose limits in 10 CFR 20.1301. Two options are to either demonstrate that the annual dose limit is not exceeded, or demonstrate that (a) "the annual average concentrations of radioactive material released in gaseous and liquid effluents at the boundary of the unrestricted area do not exceed the values specified in Table 2 of Appendix B to Part 20," and (b) "if an individual were continuously present in an unrestricted area, the dose from external sources would not exceed $0.002 \mathrm{rem}$ $(0.02 \mathrm{mSv})$ in an hour and $0.05 \mathrm{rem}(0.5 \mathrm{mSv})$ in a year."

For the purposes of used fuel reprocessing facility research and development, planning, and preliminary design, the following considerations apply.

(i) Emissions of volatile radionuclides are assumed to be constant over a year-so the short-term limit of $0.002 \mathrm{rem}(0.02 \mathrm{mSv})$ in 20.1302(b)(2)(ii) is not considered, since the lower annual limit is more restrictive than this hourly limit when annualized.

(ii) The dose limit from 10 CFR 20.1301 is $0.1 \mathrm{rem}(1 \mathrm{mSv})$ per year, but the demonstration of compliance level in 10 CFR 20.1302 is one-half of that, at $0.05 \mathrm{rem}$ $(0.5 \mathrm{mSv})$ per year.

(iii) Table 2 of 10 CFR 20 (Appendix B) defines limits for annual average concentrations of radioactive material released in gaseous and liquid effluents at the boundary of an unrestricted area (the "fence line" that would surround a UNF reprocessing facility). These limits are based on an annual dose limit to an individual member of the public in the unrestricted area (just outside the fence line) of $0.05 \mathrm{rem}(0.5 \mathrm{mSv})$. For conservatism and simplicity in this study, we consider only these annual average concentrations because they are more conservatively restrictive than analyses in which the derived air concentrations (DACs) are used to assess worker annual limits on intake (ALIs) and analyses in which the basis is the short-duration $1 \mathrm{~h}$ exposure limits to the public.

(iv) Since the annual limit of $0.05 \mathrm{rem}(0.5 \mathrm{mSv})$ in $10 \mathrm{CFR}$ 20.1302(b)(2)(ii) is higher than the annual limit of $25 \mathrm{mrem} / \mathrm{y}(0.25 \mathrm{mSv})$ from 40 CFR 190, we consider that volatile radionuclide control efficiencies that provide compliance to 40 CFR 190 will also provide compliance to 10 CFR 20.

(v) According to Regulatory Guide 8.37 [4], a dose limit to a member of the public of $10 \mathrm{mrem} / \mathrm{y}(0.1 \mathrm{mSv} / \mathrm{y})$ should be achievable based on NRC-licensed facilities that have been surveyed. So the NRC may consider a $10 \mathrm{mrem} / \mathrm{y}$ [0.1 mSv/y] limit to be ALARA even though the limit in 10 CFR 20.1302(b)(2)(ii) is higher, 
TABLE 1: The US radionuclide air emission regulations.

\begin{tabular}{lcc}
\hline Regulation & $\begin{array}{c}\text { Dose equivalent to public, } \\
\mathrm{mrem} / \mathrm{y}(\mathrm{mSv} / \mathrm{y})\end{array}$ & $\begin{array}{c}\text { Max fuel cycle emissions per GWy } \\
\text { electric energy }\end{array}$ \\
\hline Nuclear fuel cycle (40 CFR 190.10) [2] & $25(0.25)$ to whole body; & $\begin{array}{c}85 \mathrm{Kr}:<50000 \mathrm{Ci}(<1.85 \mathrm{E} 6 \mathrm{GBq}) ; \\
129 \mathrm{I}:<5 \mathrm{mCi}(<0.185 \mathrm{gBq})\end{array}$ \\
\hline & $25(0.25)$ to any other organ & - \\
NRC licensees (10 CFR 20.1101, .1301, & Dose limit: $100(1)$ \\
.1302 , App. B) [3] & Compliance demonstration \\
& limit: $50(0.5)$ & - \\
\hline DOE facilities (40 CFR 61.92) [4] & $10(0.1)$ & - \\
\hline
\end{tabular}

TABLE 2: Estimated DFs required for the volatile radionuclides for different selected types of used fuels and burn-ups.

\begin{tabular}{|c|c|c|c|c|c|c|}
\hline \multirow[t]{2}{*}{ Nuclide } & \multicolumn{3}{|c|}{$\begin{array}{l}\text { Assumed dose limit for the volatile radionuclides }=25 \mathrm{mrem} / \mathrm{y} \\
\text { and } 75 \mathrm{mrem} / \mathrm{y} \text { to thyroid ( } 40 \text { CFR 190) }\end{array}$} & \multicolumn{3}{|c|}{$\begin{array}{l}\text { Assumed dose limit }=2.5 \mathrm{mrem} / \mathrm{y} \text { and } 7.5 \mathrm{mrem} / \mathrm{y} \text { to thyroid } \\
\text { (10\% of the } 40 \text { CFR } 190 \text { limits) }\end{array}$} \\
\hline & $\begin{array}{c}\text { PWR/UOX, } \\
\text { BU = } 60 \\
\text { GWd/tIHM }\end{array}$ & $\begin{array}{c}\text { PWR/MOX, } \\
\text { BU = } 100 \\
\text { GWd/tIHM }\end{array}$ & $\begin{array}{c}\text { AHTGR } \\
\text { BU }=100 \\
\text { GWd/tIHM }\end{array}$ & $\begin{array}{c}\text { PWR/UOX, } \\
\text { BU = } 60 \\
\text { GWd/tIHM }\end{array}$ & $\begin{array}{c}\text { PWR/MOX, } \\
\text { BU = } 100 \\
\text { GWd/tIHM }\end{array}$ & $\begin{array}{c}\text { AHTGR } \\
\text { BU = } 100 \\
\text { GWd/tIHM }\end{array}$ \\
\hline${ }^{3} \mathrm{H}$ & $\begin{array}{l}25 \text { ( } 1 \text { after } 57 \mathrm{y} \\
\text { cooling) }\end{array}$ & $\begin{array}{l}160 \text { (1 after } 90 \mathrm{y} \\
\quad \text { cooling) }\end{array}$ & $\begin{array}{l}42 \text { (1 after } 66 \text { y } \\
\text { cooling) }\end{array}$ & $\begin{array}{l}600 \text { (1 after } 110 \mathrm{y} \\
\text { cooling) }\end{array}$ & $\begin{array}{l}720 \text { (1 after } 120 \mathrm{r} \\
\text { cooling) }\end{array}$ & $\begin{array}{l}590 \text { (1 after } 110 \mathrm{y} \\
\text { cooling) }\end{array}$ \\
\hline${ }^{14} \mathrm{C}$ & 1 & 1 & 4 & 10 & 15 & 30 \\
\hline${ }^{85} \mathrm{Kr}$ & $\begin{array}{l}9 \text { (1 after } 34 \text { y } \\
\text { cooling) }\end{array}$ & $\begin{array}{l}4.2(1 \text { after } 22 \mathrm{y} \\
\text { cooling) }\end{array}$ & $\begin{array}{l}9.2 \text { ( } 1 \text { after } 34 \text { y } \\
\text { cooling) }\end{array}$ & $\begin{array}{l}18 \text { ( } 1 \text { after } 45 y \\
\text { cooling) }\end{array}$ & $\begin{array}{l}13 \text { ( } 1 \text { after } 40 \mathrm{y} \\
\text { cooling) }\end{array}$ & $\begin{array}{l}62(1 \text { after } 64 \text { y } \\
\text { cooling) }\end{array}$ \\
\hline${ }^{129} \mathrm{I}$ & 380 & 630 & 650 & 3800 & 8000 & 6600 \\
\hline \multicolumn{7}{|c|}{$\begin{array}{l}\text { (1) PWR: pressurized water reactor. } \\
\text { (2) UOX: used uranium oxide fuel. } \\
\text { (3) MOX: mixed U and Pu oxide fuel. } \\
\text { (4) GWd/tIHM: Gigawatt-day per tonne initial heavy metal. } \\
\text { (5) AHTGR: advanced high temperature gas reactor. } \\
\text { (6) BU: fuel burn-up. The }{ }^{3} \mathrm{H} \text { and }{ }^{14} \mathrm{C} \text { DFs are based on the whole body dose limits-the doses to the organs are less restrictive. The }{ }^{85} \mathrm{Kr} \text { DFs are based on the } \\
\text { fuel cycle emission limit and the whole body dose limits-the doses to the organs are less restrictive. The iodine DFs are based on control efficiencies needed } \\
\text { to meet the fuel cycle emission limit and the thyroid dose limit-the whole body dose is less restrictive. } \\
\text { (7) These DF values have been rounded to not more than two significant figures. }\end{array}$} \\
\hline
\end{tabular}

at $50 \mathrm{mrem} / \mathrm{y}(0.5 \mathrm{mSv} / \mathrm{y})$. In that case, the $25 \mathrm{mrem} / \mathrm{y}$ limit in 40 CFR 190 is not the bounding case. In part for this reason, calculations of volatile radionuclide control efficiencies in this paper are based on dose limits between 2.5 and $25 \mathrm{mrem} / \mathrm{y}$ (0.025 to $0.25 \mathrm{mSv} / \mathrm{y})$.

\subsection{CFR 61: National Emission Standards for Hazardous Air} Pollutants, Subpart H-National Emission Standards for Emissions of Radionuclides Other Than Radon from Department of Energy Facilities, 61.92. This part applies to radionuclide emissions other than ${ }^{222} \mathrm{Rn}$ and ${ }^{220} \mathrm{Rn}$ from DOE facilities, except that this part does not apply to disposal at facilities subject to 40 CFR Part 191 Subpart B or 40 CFR Part 192 [5]: "emissions of radionuclides to the ambient air from Department of Energy facilities shall not exceed those amounts that would cause any member of the public to receive in any year an effective dose equivalent of $10 \mathrm{mrem} / \mathrm{yr}$." This dose limit for DOE facilities equals the ALARA-based limit from 10 CFR 20 and is in the range of dose limits between 2.5 and $25 \mathrm{mrem} / \mathrm{y}$ ( 0.025 to $0.25 \mathrm{mSv} / \mathrm{y})$ used in this paper.

\section{Control Efficiency Requirements}

A question that has persisted for years is how efficiently must the volatile radionuclides be captured to ensure that a reprocessing facility in the US will comply with air emission regulations? Such a simple question, in the case of volatile radionuclides, has a complicated answer-or at least an answer or range of answers - that must be accompanied by a list of assumptions. Control efficiencies needed for compliance to the fuel cycle isotope-specific limits specified in of 40 CFR 190 for ${ }^{129} \mathrm{I}$ and ${ }^{85} \mathrm{Kr}$ per GWy of electrical energy produced in the fuel cycle can be estimated from the following.

(i) The amount of ${ }^{129} \mathrm{I}$ and ${ }^{85} \mathrm{Kr}$ in UNF. The amount of these nuclides in UNF depends mainly on the fuel burn-up, reactor conditions during burn-up, and aging (cooling) time after reactor discharge.

(ii) The proportions of these nuclides released in process liquid or other streams, and the proportions released to reprocessing facility off-gas streams (and would be released to the atmosphere if not captured). 
(iii) The thermal efficiency of the nuclear reactor.

(iv) The estimated values for any release of ${ }^{129} \mathrm{I}$ and ${ }^{85} \mathrm{Kr}$ in other parts of the fuel cycle besides the reprocessing facility.

Estimating dose-based removal efficiencies needed to ensure compliance to regulatory dose limits in 40 CFR 60.190, 40 CFR 61.92, or 10 CFR 20 is more complex and requires additional site-specific information. In addition to the bullets listed above, the following factors must be considered or assumed.

(i) Volatile radionuclide mass emission rates from the stack and mass emission rates of all other radionuclides from the stack. These rates depend on the amount of the volatile and other nuclides in the UNF, the reprocessing facility throughput, and the portions of these nuclides that are released to off-gas streams during reprocessing. Since all emitted radionuclides contribute to the total dose, the amount of the dose from any single radionuclide must be reduced to the extent needed to ensure that the cumulative dose from all the radionuclides is within the regulatory limit.

(ii) Many air dispersion and dose parameters, the most important of which are.

(a) Stack gas parameters-stack gas flow rate, exit gas momentum (a function of the gas exit velocity and density).

(b) Speciation of the volatile radionuclides.

(c) Site-specific meteorological parameters.

(d) Site-specific agricultural parameters.

(e) Other site-specific parameters including distance from the stack (or stacks) to the accesscontrolled boundary (fence-line) up to which the public can approach and theoretically live and subsist). A person at this distance, in the direction of the highest average plume concentration from the $\operatorname{stack}(\mathrm{s})$, is termed the maximally exposed individual (MEI).

(f) The air dispersion model used to calculate dispersal of the plume out to the location of the MEI.

(g) Dose conversion factors used in the dose model.

Estimated volatile radionuclide control efficiencies needed to meet regulatory compliance in the US have been provided in previous studies [6-8]. The most recent and, in our view, comprehensive study of volatile radionuclide control efficiencies is reported by Jubin et al. [9].

Estimated decontamination factors (DFs) from Jubin et al. [9] to meet the regulations are shown in Table 2. The DF is the amount of a nuclide in the off-gas stream(s) divided by the amount in the off-gas stream downstream of the offgas control system. In other terms, the DF $=1 /(1-$ (control efficiency\%/100)). The DF values in this table have been used to provide direction and scope for volatile radionuclide control research and development, but they depend on the following assumptions. (i) The fuel burn-ups shown here represent the maximum currently reasonable burn-up ranges for these fuel and reactor combinations; fuels with lower burnups would have lower DFs (down to DF =1) and, for the shorter-lived ${ }^{3} \mathrm{H}$ and ${ }^{85} \mathrm{Kr}$ compared to ${ }^{3} \mathrm{H}$ and ${ }^{129} \mathrm{I}$, shorter cooling times until when no control is needed.

(ii) Of the volatile radionuclides in the UNF, $100 \%$ is assumed to evolve into the reprocessing facility offgas; no emissions of these volatile radionuclides are assumed to be released in other parts of the nuclear fuel cycle, that is, fuel production, reactor operation, and so forth, and no migration is assumed, for example, ${ }^{3} \mathrm{H}$ migration into and retention in the Zircaloy cladding, which would result in a decrease in the calculated radionuclide inventory.

(iii) Reprocessing facility throughput: $1000 \mathrm{tIHM} / \mathrm{y}$ (tonnes (metric tons) of initial heavy metal per year). Smaller reprocessing plants could have smaller DFs (down to DF $=1$ ) and shorter cooling times until DF $=1$ for ${ }^{3} \mathrm{H}$ and ${ }^{85} \mathrm{Kr}$. Larger reprocessing plants will need larger DFs and longer cooling times until DF = 1 for ${ }^{3} \mathrm{H}$ and ${ }^{85} \mathrm{Kr}$.

(iv) No engineering safety factors are assumed.

(v) The DF calculations are based on control efficiencies needed to comply with the fuel cycle emission limits for ${ }^{129} \mathrm{I}$ and ${ }^{85} \mathrm{Kr}$ and whole body, thyroid, and other organ dose calculations to the MEI.

(vi) Doses to the MEI are calculated with the US EPA Clean Air Act Assessment Package (CAP88-PC Version 3.0) computer model CAP88 $[10,11]$. This model is a set of computer programs, databases, and associated utility programs used to estimate dose and risk to members of the public from radionuclide emissions in the air. Version 3.0 of CAP88 incorporates dose and risk factors from the Federal Guidance Report 13 [12] that are based on the methods of the International Commission on Radiological Protection [13].

(vii) The reprocessing facility site boundary is assumed to be the location of the MEI and is the distance from and in the direction of the maximum plume concentrations as determined with the CAP88 code. This can result in dose-based DF estimates that are conservatively high relative to the dose-based DFs for other site boundary and locations that are not at the location of the MEI.

(viii) With the dose limit of $25 \mathrm{mrem} / \mathrm{y}(0.25 \mathrm{mSv} / \mathrm{y})$ from 40 CFR 190, no allowance is assumed for any other nuclide emissions besides these four volatile radionuclides and the presumed ALARA level of $10 \mathrm{mrem} / \mathrm{y}$ $(0.1 \mathrm{mSv} / \mathrm{y})$ from $10 \mathrm{CFR} 20$ is not considered. The dose limit of $2.5 \mathrm{mrem} / \mathrm{y}(0.025 \mathrm{mSv} / \mathrm{y})$ bounds the presumed ALARA level of $10 \mathrm{mrem} / \mathrm{y}(0.1 \mathrm{mSv} / \mathrm{y})$ 
from 10 CFR 20 and reserves from $75 \%$ to $90 \%$ of the total allowable dose for the potential emissions of other dose contributors $(75 \%$ in the case of the $10 \mathrm{mrem} / \mathrm{y}(0.1 \mathrm{mSv} / \mathrm{y})$ ALARA value; and $90 \%$ in the case of the $25 \mathrm{mrem} / \mathrm{y}(0.25 \mathrm{mSv} / \mathrm{y}) 40$ CFR 190 limit).

The amount of the volatile radionuclides in UNF varies depending on assumptions (Figure 1). The control efficiencies needed for the volatile radionuclides to meet the assumed dose limits are generally proportional to the amounts of volatile radionuclides and the UNF reprocessing rates, down to a $\mathrm{DF}=1$. The amounts of volatile radionuclides in UNF were calculated with the Oak Ridge Isotope Generation and Depletion (ORIGEN) code Automatic Rapid Processing (ARP) simulations [9]. The concentrations of chemical impurities in the starting $\mathrm{UO}_{2}$ and $\mathrm{PuO}_{2}$ materials are assumed to be one-half of the maximum values shown in the standard specifications by the American Society for Testing and Materials (ASTM) $[14,15]$.

About $80 \%$ of the ${ }^{14} \mathrm{C}$ in UOX UNF is from activation of the impurity ${ }^{14} \mathrm{~N}$, and most of the remainder is from the activation of ${ }^{17} \mathrm{O}$, which has a natural abundance of $0.038 \mathrm{~mol} \%$. Most of the ${ }^{14} \mathrm{C}$ in the used tristructural isotropic (TRISO) fuel from an advanced high-temperature gas reactor (AHTGR) is from the activation of (a) ${ }^{13} \mathrm{C}$ (with a natural abundance of $1.1 \mathrm{~mol} \%$ ) in the carbon in the assumed TRISO fuel pebble, (b) ${ }^{14} \mathrm{~N}$, an impurity assumed in the uranium oxycarbide fuel core of TRISO kernels, and (c) ${ }^{17} \mathrm{O}$ isotope in the uranium oxycarbide. Different assumptions for impurity levels, fuel compositions, and fuel configurations result in different levels of volatile radionuclides in the used fuels.

Assumptions in addition to those shown above for UNF, reprocessing facility size, and CAP88 model were included in sensitivity studies [9]. Sensitivity studies of the site-specific parameters in the CAP88 model indicate the following.

(i) Increasing the emissions stack height by a factor of 4 (from $37 \mathrm{~m}$ to $150 \mathrm{~m}$ ) resulted in a factor of $\sim 16$ reduction in the dose to the MEI.

(ii) Changing the speciation of ${ }^{129}$ I from $100 \%$ particulate that was used in the calculations of this study to $30 \%$ to $70 \%$ particulate (a range consistent with measurements from the Karlsruhe Reprocessing Plant [16]) would reduce the ${ }^{129}$ I dose to $30 \%$ to $70 \%$ of the $100 \%$ particulate value.

(iii) Changing the stack gas velocity and temperature can affect the dose to the MEI by up to a factor of 2, depending on the character of the plume (momentum or buoyancy dominated).

(iv) Site-specific meteorological parameters can (a) cause the ${ }^{3} \mathrm{H}$ dose to vary by a factor of 2 depending on the humidity, (b) increase the dose from ${ }^{14} \mathrm{C}$ and ${ }^{129} \mathrm{I}$ by more than $10 \%$ in areas with higher precipitation, and (c) cause the dose from any of the volatile radionuclides to vary by more than $20 \%$ for different wind velocities. (v) Site-specific agricultural parameters, which vary for different locations in the US, affect dose from ingestion. Changing from the rural food scenario to an urban food scenario decreases the doses from those volatile radionuclides that play a role in the food cycle $\left({ }^{3} \mathrm{H},{ }^{14} \mathrm{C}\right.$, and $\left.{ }^{129} \mathrm{I}\right)$ by $30-40 \%$. The dose from ${ }^{85} \mathrm{Kr}$ is unchanged because it does not play a role in the food cycle.

\section{History of Iodine and Krypton Capture}

Both iodine and krypton capture have been used in various UNF reprocessing facilities worldwide. In addition, technologies for scrubbing iodine and other halogen gases and for separating noble gases, including $\mathrm{Kr}$ and $\mathrm{Xe}$, are commercially available and used in industrial, nonradioactive processes.

4.1. Iodine Capture. Two types of technologies that have been developed and used for capturing gaseous ${ }^{129} \mathrm{I}$-bearing components from reprocessing facility off-gas streams are caustic or acidic scrubbing solutions and chemisorption on silvercoated or -impregnated adsorbents. (During reprocessing, ${ }^{131} \mathrm{I}$ is generated from the fission of ${ }^{244} \mathrm{Cm}$. We have not considered this source of iodine, because with the short halflife, it is unlikely to have any impact on the results discussed here). These processes are not selective to just iodine, but they also capture other halogen-bearing components that could be present in the off-gas streams. Some of these technologies have an affinity for other volatile radionuclides, such as ${ }^{14} \mathrm{C}$, ${ }^{3} \mathrm{H}$, and ${ }^{85} \mathrm{Kr}$, thereby complicating later disposal.

Some specialized iodine wet scrubber concepts have been developed or used for gaseous iodine control, including caustic scrubbing, Iodox, and Mercurex [17, 18]. Caustic scrubbing for iodine capture is a relatively mature process; it is included in the dissolver off-gas control system at the La Hague Reprocessing Facility in France, the Windscale and the Thermal Oxide Reprocessing Plant (THORP) facilities in the United Kingdom [18], and the Rokkasho Reprocessing Plant in Japan. Past testing has shown that moderately high iodine DFs of 50-150 are possible with caustic scrubbing [17, 19], but it may not efficiently capture organic iodides.

The Iodox process was developed to capture ${ }^{131}$ I released when reprocessing liquid metal fast breeder reactor (LMFBR) fuel [18], when the fuel is only cooled 180 days after reactor discharge. High concentrations of $\mathrm{HNO}_{3}$ are used in this process. In nonradioactive engineering tests, DFs up to $10^{6}$ were achieved. While both elemental and organic forms of iodine may be captured with this method, it requires several peripheral processes including the ability to concentrate the $\mathrm{HNO}_{3}$, recycle the acid, and treat the waste stream.

Like the Iodox process, the Mercurex process was also developed for the treatment of the dissolver off-gas evolved during the processing of very short cooled fuels where very high DFs are required [18]. In this process, a $\mathrm{Hg}\left(\mathrm{NO}_{3}\right)_{2}-$ $\mathrm{HNO}_{3}$ solution is used in a wet scrubber. Gaseous iodine is absorbed in solution to form mercury iodate and iodide complexes. Mercurex was used at Dounreay, Scotland, and Nuclear Fuel Services at West Valley, New York, with reported 

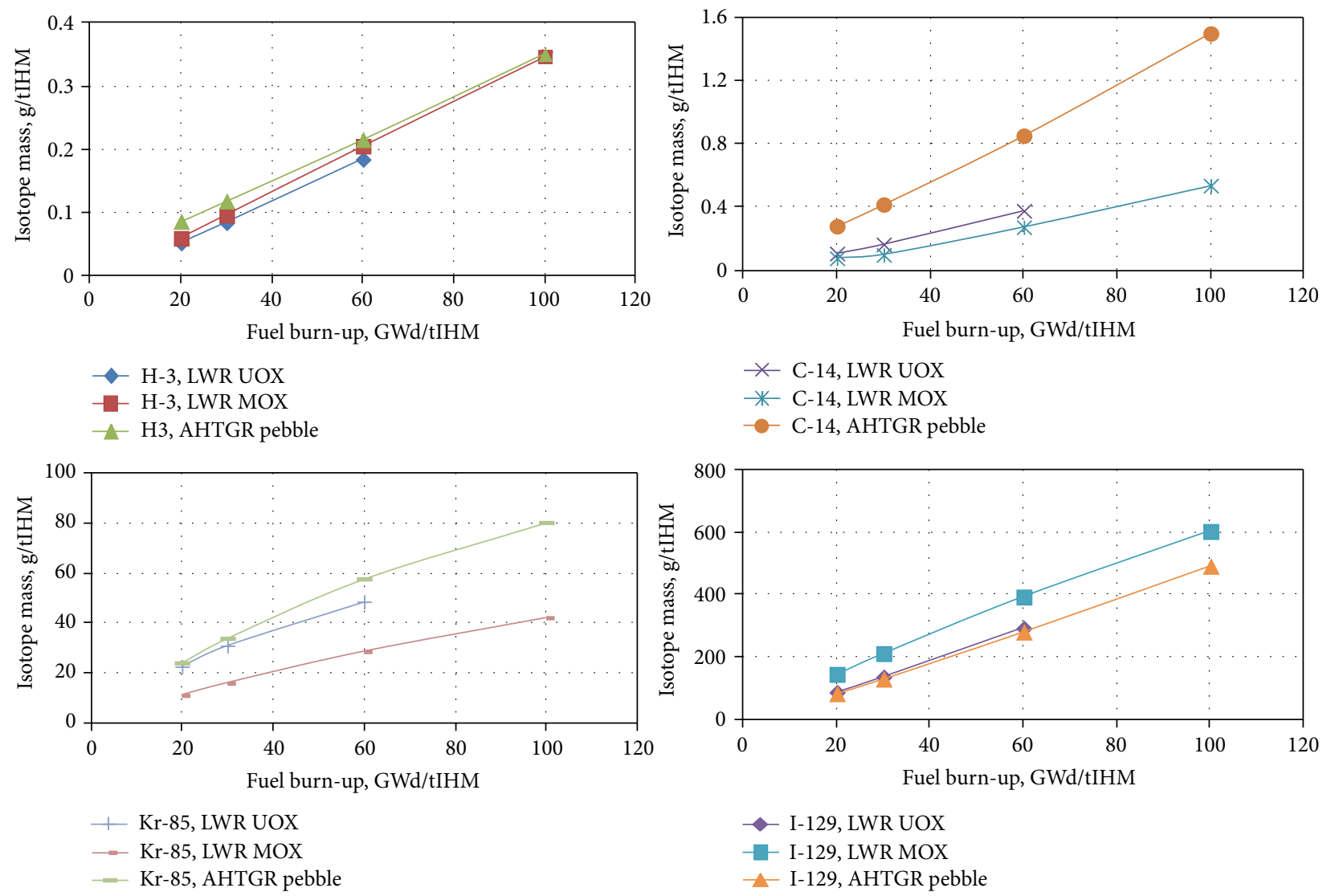

FIGURE 1: Amounts of volatile radionuclides in selected UNFs at the time of discharge (no cooling time), calculated with ORIGIN-ARP [9].

DFs of 150 and 32, respectively [15]. Mercurex was considered for use in the British Nuclear Fuels Limited reprocessing plant (BNFL) and Eurochemic in Belgium. Decontamination factors of 10-75 were claimed [18].

Adsorption of iodine on solid sorbents coated or impregnated with a metal, such as silver, has been studied and used in a few applications for decades. The presence of a metal, such as Ag, provides for chemical reaction of the gaseous iodine to form the metal halide. Chemisorption converts the sorbed form of iodine into a much less volatile material than the incoming gaseous form (expectedly $\mathrm{I}_{2}$, but also possibly $\mathrm{HI}$ and organic iodides, such as $\mathrm{CH}_{3} \mathrm{I}$ ).

Silver nitrate-coated ceramic saddles were used at the Hanford Purex Plant and the Savannah River Plant to remove ${ }^{131}$ I from off-gas streams [16]. The process involved passing the dissolver off-gas through a bed of heated ceramic saddles glazed with silver nitrate with which the iodine components of the off-gas would react to form AgI. Silver reactors have demonstrated DFs of 10 to $10^{4}$ for ${ }^{131}$ I recovery [16].

Silver nitrate-impregnated alumina (AgA) has been studied for capturing ${ }^{131}$ I from off-gas streams and developed for treating off-gas streams at the Tokai Reprocessing Plant in Japan [19-22]. Silver nitrate-impregnated alumina with 10 and 24 mass\% $\mathrm{Ag}$ is reported to have iodine adsorption capacities of about $0.12 \mathrm{Mg} / \mathrm{m}^{3}$ and about $0.35 \mathrm{Mg} / \mathrm{m}^{3}$, respectively [23]. Decontamination factors over 1000 were achieved [23].

The use of silver-exchanged zeolite (AgZ) sorbent is the leading approach in the US for capturing radioactive gaseous byproducts, such as $\mathrm{I}_{2}$, during nuclear fuel reprocessing. This is because of expected high control efficiencies based on the solid sorbent mass transfer zone concept and the acid resistance of the zeolite compared to other substrates such as faujasite $(\mathrm{AgX})$. Published studies surveyed by Thomas et al. [24] indicate $\mathrm{I}_{2}$ loadings on silver-exchanged faujasite or $\mathrm{AgZ}$ ranged from 80 to $200 \mathrm{mg} / \mathrm{g}$ while maintaining decontamination factors in the range of 100 to 10000 for $\mathrm{I}_{2}$. Methyl iodide loadings of 140 to $180 \mathrm{mg} / \mathrm{g}$ are reported from tests on simulated dissolver off-gas streams $[25,26]$.

Indeed, for many decades, AgZ has been a benchmark for radiological $I_{2}$ capture $[18,22,27]$. Generally, AgZ is believed to benefit from high-efficiency adsorption, a high Sito-Al ratio that enhances stability in acidic off-gas streams, relatively high Ag contents, and no flammability.

The base material used in the studies conducted in the 1970 s and 1980s was a binderless synthetic mordenite (Zeolon 900) produced by Norton (Akron, OH, USA). The sodium form of Zeolon 900 was ion exchanged with silver from a silver nitrate solution. After exchange, the silver content in the $\mathrm{AgZ}$ was $\sim 18$ mass $\%$. This material is no longer available commercially, so recent AgZ studies have to address the 
quality of and differences between currently available natural and synthetic mordenites. The iodine capacities for different $\mathrm{AgZ}$ sorbents varied, introducing some uncertainty in the ability to achieve the DF values reported in the 1970 s and 1980s.

Aerogels are being considered for capturing iodine compounds in the reprocessing plant off-gas. Aerogels start as a gel from which the solvent(s) is removed, typically with supercritical $\mathrm{CO}_{2}$. This results in materials with very high porosity and surface area. Two aerogel materials are being considered: functionalized silica aerogels and chalcogels. Silica aerogels are available commercially. A functional group is tied to the silica surface inside the aerogel pores with an organic moiety that has silica-binding functionality on one end of the molecule and a Ag-specific functionality on the other. After functionalizing the pore surface, aqueous $\mathrm{Ag}^{+}$is added and subsequently reduced to $\mathrm{Ag}^{0}$.

A key advantage of a silica aerogel sorbent is that, after loading with iodine, it can be consolidated into a dense and leach-resistant waste form. The density of the $\mathrm{SiO}_{2}$ aerogel is about $1.9 \mathrm{~kg} / \mathrm{m}^{3}$. The density of iodine loaded silver functionalized aerogel is about $26 \mathrm{~kg} / \mathrm{m}^{3}$. Because of this low density, a granular form of Ag-functionalized aerogel is needed. The density of the iodine-laden aerogel after collapsing can be as high as $4000 \mathrm{~kg} / \mathrm{m}^{3}$.

Chalcogel is made from S-, Se-, or Te-bearing starting materials that are caused to crosslink in the presence of certain metal ions, such as $\mathrm{Pt}$ and $\mathrm{Cu}$ [28]. Chalcogels also have very high surface areas and porosities but do not need to be functionalized. In the case of chalcogel, the iodine compounds are soluble in the matrix of the material. Because of this, adsorption on chalcogel can be quite high, 100 to 200 mass $\%$, relative to the starting material and 25 to 50 mass $\%$, relative to the end product. The chalcogel density is about $3000 \mathrm{~kg} / \mathrm{m}^{3}$. When fully loaded with iodine, the density is about $4300 \mathrm{~kg} / \mathrm{m}^{3}$. These materials are not available commercially. As with the silica aerogel, a granular form is needed.

Metal-organic framework structures (MOFs) are viewed by many as the next generation of porous materials with promising applications in many areas $[29,30]$. Gas sorption is the main focus of many MOF studies [31, 32] because of their high adsorptive capacity associated with very large surface areas and porosity $[33,34]$ and the ability to "tune" the organic moiety for specificity. At the same time, studies of gas separation are also becoming more widespread given that MOF structures are highly tunable towards specific applications [35].

4.2. Krypton Capture. The capture of noble gases can be achieved either by the use of cryogenic methods or by physical adsorption on solid matrices (e.g., molecular sieves, metal-organic frameworks, or porous organic polymers). Numerous candidate technologies have been investigated for the capture of $\mathrm{Kr}$ and $\mathrm{Xe}$ from UNF reprocessing offgas streams. Here, we provide a short description of each technology.
4.2.1. Cryogenic Distillation. Of all noble gas separation technologies, cryogenic distillation is considered to be the most mature. Cryogenic separation of $\mathrm{Kr}$ and $\mathrm{Xe}$ from air is done commercially at air separations plants and provides 99.999\% pure $\mathrm{Kr}$ and $\mathrm{Xe}$. The principle operating basis is to utilize the differences in boiling points between the gases targeted for separation.

Cryogenic distillation units have been used at nuclear fuel reprocessing plants for several decades in the US and more recently in Japan [36-38]. Krypton decontamination factors of 100-1000 have been reported that would meet anticipated regulatory ${ }^{85} \mathrm{Kr}$ emission requirements [39]. Although these processes did not always achieve optimum ${ }^{85} \mathrm{Kr}$ decontamination, the successful operation did confirm the feasibility of the technology.

Some reprocessing facility off-gas pretreatment is necessary prior to cryogenic treatment. Nitrogen dioxide and other impurities are removed with a caustic scrubber. The scrubbed effluent contains mostly air, much reduced amounts of $\mathrm{NO}_{x}$, small amounts of hydrogen, and rare gases. This effluent gas is stored in tanks. The stored gases are then processed through a rhodium catalyst bed at $540-650^{\circ} \mathrm{C}(813-$ $923 \mathrm{~K})$, in which the $\mathrm{NO}_{x}$ is reduced to nitrogen and the small amount of hydrogen reacts with oxygen to form water. The effluent from the catalytic reduction is then cooled, demisted, and dried before being sent to the cryogenic distillation process. The distillation process consists of heat exchangers, distillation column, and a batch still. The pretreated gas is cooled with heat exchangers and then sent to the cryogenic column where the $\mathrm{O}_{2}, \mathrm{Kr}, \mathrm{Xe}$, and $\mathrm{Ar}$ are absorbed into countercurrent stream of liquid nitrogen. The uncondensed gases are released to the atmosphere. The absorbed gases are continuously concentrated and then collected in a batch still where the absorbed gases are selectively distilled.

The technology has certain drawbacks, one of which is the radiolytic formation of concentrated ozone that can be an explosion hazard. This hazard is minimized by complete removal of oxygen from the process gas or intermittent flushing to remove the ozone.

4.2.2. Fluorocarbon Absorption. A selective absorption process in which dichlorodifluoromethane $\left(\mathrm{CCl}_{2} \mathrm{~F}_{2}\right.$, also known as Freon-12 or R-12) is used was developed and tested at Oak Ridge National Laboratory and the Karlsruhe Research Center (formerly Forschungszentrum Karlsruhe) in Germany $[40,41]$. This process is very similar to the cryogenic distillation process, but operated at higher temperatures and pressures.

The basis for this process lies within the solubility differences between the gas components in the solvent. Gas components can be removed from upper, middle, and lower sections of a single column. However, solvent carryover in product streams is a problem. The process gas stream is compressed and then cooled before it is injected into a column where it is bubbled through the freon. The $\mathrm{Kr}$ and $\mathrm{Xe}$ are absorbed into the freon and captured in the middle region of the column. Relatively pure $\mathrm{Kr}$ and $\mathrm{Xe}$ (with some solvent) 
are removed from the column. Krypton removal efficiencies of $99 \%$ have been achieved with these systems.

Capital equipment and operating costs are similar to the cryogenic process. The absorption process is operated around $-30^{\circ} \mathrm{C}(243 \mathrm{~K})$ resulting in reduced refrigeration costs; however, higher operating pressures of $2.8 \mathrm{MPa}$ (400 psig) can result in product losses from potential process gas leaks. Solvent costs are relatively low, but process leakage, volatilization, and radiolysis degradation combine to increase the costs.

Explosion hazards from ozone or Xe-tetrafluoride are reduced with the absorption process. This process has never been tested at plant scale.

4.2.3. Carbon Dioxide Absorption. This process is very similar to the fluorocarbon absorption process in terms of capital equipment and operating costs. The primary difference is the use of $\mathrm{CO}_{2}$ as the solvent. The process is considered a potential candidate for use with gas streams rich in $\mathrm{CO}_{2}$, such as could occur in the reprocessing of graphite fuels [4244]. While $\mathrm{CO}_{2}$ is readily available, the process is limited to only those gas streams with high $\mathrm{CO}_{2}$ concentrations. Explosion hazards and radiolytic degradation have not been experienced in limited scoping studies. The scoping studies were mainly to evaluate basic absorption data for $\mathrm{CO}_{2}$, so decontamination factor results were limited.

4.2.4. Selective Physical Adsorption. This technology is considered the simplest to operate of the off-gas treatment processes. Within a single temperature or pressure setting, $\mathrm{Kr}$ and $\mathrm{Xe}$ can be physically adsorbed into the pores of a selective sorbent material in the column. These operating conditions are commonly referred to as temperature swing adsorption (TSA) or pressure swing adsorption (PSA), where lower temperatures or higher pressures, respectively, result in greater sorbent capacities. The $\mathrm{Kr}$ and $\mathrm{Xe}$ can then be desorbed from the pores at increased temperature or decreased pressure [45].

Activated charcoal is well known as a material for the capture of $\mathrm{Kr}$ and $\mathrm{Xe}$ at reduced temperatures. The primary drawback of charcoal is the potential for fires during the thermal desorption stage because of the $\mathrm{NO}_{x}$ in the gas stream. Both natural and synthetic zeolites are known to have the proper cage structure and frameworks that result in high surface areas and a pore size conducive for $\mathrm{Kr}$ and Xe capture and are considered to be a suitable substitute to activated charcoal.

Zeolites have been studied for $\mathrm{Kr}$ recovery [18]. Xenon can be captured at ambient temperatures with AgZ. The "Xe free" gas is then chilled and passed through hydrogen mordenite (HZ) operated on which the $\mathrm{Kr}$ is adsorbed at $\sim 80^{\circ} \mathrm{C}(\sim 190 \mathrm{~K})$. The $\mathrm{HZ}$ bed is bypassed and heated to $\sim 60^{\circ} \mathrm{C}(\sim 330 \mathrm{~K})$ to desorb the $\mathrm{Kr}$ and regenerate the $\mathrm{HZ}$; the desorbed $\mathrm{Kr}$ is captured on a second, offline $\mathrm{HZ}$ bed from which it is recovered with a temperature swing to a cold trap [46]. The Xe bed is regenerated at 200 to $250^{\circ} \mathrm{C}(473$ to $523 \mathrm{~K})$. Laboratory tests have shown DFs of 400 for Kr and 4000 for $\mathrm{Xe}$ [47].
The sorbent bed volumes associated with physisorption can be significantly reduced by the use of cryogenic temperatures, incurring the higher costs associated with refrigeration. The potential for enhanced safety coupled with reduced capital and operating costs supports further development as a viable process option.

\section{Recent Advances in Iodine and Krypton Capture}

Estimated required ${ }^{129} \mathrm{I}$ DFs exceed 1000 [9]. Estimated required ${ }^{85} \mathrm{Kr}$ DFs exceed 10 , although, as UNF ages, the required DF decreases and no ${ }^{85} \mathrm{Kr}$ control would be needed after what may be just a few years up to perhaps 60 years decay time, depending on the UNF and other assumptions [9].

5.1. Recent Advances in Iodine Capture. The challenges for iodine capture include (a) sufficiently high control efficiency and selectivity to enable a reprocessing facility to meet US air emission regulations and (b) development of a process that can result in an acceptable waste form. While processes including caustic scrubbing and Ag-impregnated aluminas, silicas, and mordenites have been tested decades earlier and used in reprocessing facilities for iodine capture, it is unclear if these processes could meet current regulations. Research and development has focused on developing, evaluating, optimizing sorbents for iodine capture, and determining iodine adsorption rates, efficiency, capacity, and waste form development.

Recent results of iodine sorbent research and development are summarized from many separate Off-Gas Sigma Team reports in [1]. Experimental capabilities have been designed, built, and used for iodine adsorption testing. These include thin-bed and deep-bed iodine adsorption test systems. Many experiments have been performed with these experimental facilities including the following.

(i) Extended aging studies of reduced AgZ [1]: reduced iodine capture efficiency was measured with increasing air exposure. A more rapid reduction in iodine capture efficiency was measured with increasing air and moisture exposure. The sorbent capacity can be at least partially regenerated by re-reducing the silver, depending on how long the sorbent is exposed to moist air.

(ii) Measurement of iodine adsorption on tritium capture media and of water (tritiated water) on iodine capture media $[48,49]$.

(iii) Measurement of the adsorption capacity of AgZ: in thin-bed tests capacities ranged from about 3 to 6 mass $\%$ for gaseous $\mathrm{I}_{2}$ concentrations ranging from 2.5100 ppmv [1]. In deep-bed tests, capacities ranged from 3 to 17 mass $\%$ for $\mathrm{I}_{2}$ concentrations ranging from 2 to 50 ppmv [48].

(iv) Measurement of iodine sorption efficiencies: DFs up to 1000-10000 were measured, high enough to comply with air emission regulations [50]. 
(v) Estimation of mass transfer zone depths: mass transfer zone depths for $\mathrm{I}_{2}$ adsorption ranged from 12 to $50 \mathrm{~mm}$ (0.5-2 inches) for low inlet $\mathrm{I}_{2}$ concentrations ( 2 ppmv) up to 50 to $100 \mathrm{~mm}$ (2-4 inches) for higher $\mathrm{I}_{2}$ concentrations ( $\left.\sim 35 \mathrm{ppmv}\right)$ [50].

(vi) Identification of a detailed mechanism for silver reduction and migration in and out of mordenite pores. The reduction and aging of silver on the zeolite affect the iodine loading. Iodine loadings increased from 1 to 3.4 mass\% for increasing levels of silver reduction.

Silver-functionalized aerogels were developed as alternates to the silver-loaded zeolites [1]. These have high specificity, can be easily consolidated into a final waste form, and have low sorption of water. Iodine adsorption efficiencies of 99.9-99.99\% (DFs up to 1000-10 000), and capacities between 32 to 41 mass $\%$ were measured for functionalized aerogel and 6-month aged functionalized aerogel, respectively $[1,50]$. Aerogel capacities for $\mathrm{I}_{2}$ of 20-46 mass\% were demonstrated in deep-bed aerogel tests [50]. Aging tests indicated a decrease in iodine capacity of $9 \%$ after aging in a dry air stream for six months [51].

Metal-organic framework materials were also evaluated for iodine sorption [1]. These MOFs were pelletized into engineered forms for adsorption bed applications. A detailed crystallographic identification was done for $\mathrm{I}_{2}$ sorption on ZIF-8 (zeolitic imidazolate framework 8). The capacity of an engineered MOF for iodine was measured at 2.6-3.4 mass\%. Aqueous iodine capture and storage with $\mathrm{Bi}-\mathrm{I}-\mathrm{O}$ layered oxides was also studied.

5.2. Recent Advances in Krypton Capture. Recent investigations into alternative materials, such as inorganic synthetic titanosilicates and MOFs for physisorption, have resulted in a broadened field of new materials for the capture of $\mathrm{Kr}$ [5257]. Test results for hydrogen mordenite and silver mordenite have shown good capacities and selectivities for $\mathrm{Kr}$ and $\mathrm{Xe}$, indicating that they may be suitable substitutes for activated charcoal thereby eliminating the fire hazard [53, 58, 59]. Although Xe consists of stable isotopes after about 1 y of UNF aging (about 10 half-lives) and, thus, would not contribute to the regulated radionuclide release, it is present in process offgas streams at about 10 times the Kr concentrations. Thus, the presence of Xe detrimentally impacts the capture of $\mathrm{Kr}$ in that it competes for the same sites on the sorption media as $\mathrm{Kr}$ and increases waste volume. The high commercial economic value and potential reduction in waste volume may drive the separation of Xe from $\mathrm{Kr}$.

Recent $\mathrm{Kr}$ and Xe capture testing at the INL has included investigations of hydrogen and silver mordenites [60]. Synthetic mordenite powders are available commercially in hydrogen, sodium, and ammonia forms. The dimensions of the mordenite pores can be tuned for $\mathrm{Kr}$ and $\mathrm{Xe}$ specificity by removing a significant fraction of the aluminum from the framework with acid leaching without loss of crystalline structure. Engineered forms of the mordenites are commercially available in limited supply, but typically the pelletization process restricts the available porosity reducing sorbent capacities. The use of powders eliminates the reduced porosity but causes processing problems such as high differential pressures across a plant-sized fixed adsorption bed.

Recent results of $\mathrm{Kr}$ and $\mathrm{Xe}$ adsorption research and development at the INL include development of a custom cryostat for sorption tests, preparation of an engineered form of $\mathrm{H}$-mordenite, and preparation of a Ag-exchanged mordenite for $\mathrm{Kr}$ and Xe sorption [61]. The need for an engineered form with good surface area and available micropores to maximize adsorption capacity led to the development of a novel engineered sorbent form at the INL [60]. An engineered sorbent form was prepared from hydrogen mordenite bound in a selected macroporous polymer. The resultant material was analyzed for surface area and microporosity with results indicating good retention of porosity. Krypton capacities of $0.1 \mathrm{mmol} / \mathrm{g}$ for the sorbent were obtained at $191 \mathrm{~K}$, comparing well with experimental data obtained by Munakata et al. [58]. This sorbent form performed well for multiple adsorption and desorption cycles [60].

An engineered form of a silver-exchanged mordenite bound in a macroporous polymer was prepared and evaluated for $\mathrm{Kr}$ and $\mathrm{Xe}$ capacity [61]. The $\mathrm{Kr}$ capacity was found to be $0.057 \mathrm{mmol} / \mathrm{g}$ for the sorbent at $220 \mathrm{~K}$. The Xe capacity was found to be $0.46 \mathrm{mmol} / \mathrm{g}$ for the sorbent at $220 \mathrm{~K}$. These capacities compare well with the $\mathrm{Kr}$ and $\mathrm{Xe}$ capacities obtained by Munakata et al., on silver mordenite at $273 \mathrm{~K}$ [59].

Advances have been made recently at PNNL in the separation of $\mathrm{Xe}$ and $\mathrm{Kr}$ from air with MOFs. The research team synthesized three MOFs (nickel coordinated dioxobenzenedicarboxylic acid (NiDOBDC); copper coordinated with benzene-tri-carboxylic acid (CuBTC), called HKUST1 ; and a partially fluorinated metal organic framework $(\mathrm{FMOFCu})$ ) $[56,62,63]$. These MOFs have different pore geometries and functionalities to remove the $\mathrm{Xe}$ and $\mathrm{Kr}$ from air at near room temperature. All of these MOFs were shown to have high capacities for adsorbing $\mathrm{Xe}$ and $\mathrm{Kr}$ at room temperature and $100 \mathrm{kPa}$ (1 bar). The NiDOBDC MOF demonstrated the highest adsorption capacity for Xe. The uniform cylindrical pores in the NiDOBDC are believed to maximize Xe and Kr selectivity.

The NiDOBDC and HKUST-1 can selectively adsorb Xe and $\mathrm{Kr}$ at ppm concentrations from air. The NiDOBDC has a Xe capacity of $9.3 \mathrm{mmol} / \mathrm{kg}$ when the concentration of Xe is 1000 ppmv in air. Xenon separation selectivity from $\mathrm{Kr}$ of 7.3 was demonstrated for air containing 400 ppmv Xe, 40 ppmv $\mathrm{Kr}, 0.9$ volume $\% \mathrm{Ar}$, and 0.03 volume $\% \mathrm{CO}_{2}$. Test results show that the FMOFCu can also selectively partition $\mathrm{Kr}$ from $\mathrm{Kr}$ and Xe mixtures at moderate temperatures below ambient.

In comparison with other sorbents, MOFs were shown to have high adsorption capacities, high surface areas $(\sim 4 \mathrm{x}$ higher), uniform porosity, and high diffusivity. Similarly, the ability to tune the properties of MOFs by replacing nickel with another transition metal or functionalizing the organic building blocks is also advantageous compared to other sorbents. These results show that NiDOBDC is a promising MOF for the separation of Xe from a mixture of $\mathrm{Xe}$ and $\mathrm{Kr}$ at room temperature. Because of the synthetic flexibility, additional MOFs can be synthesized to further enhance both 
capacity and selectivity. It has been shown that MOFs can be used to separate $\mathrm{Xe}$ and $\mathrm{Kr}$ from air and $\mathrm{Xe}$ from $\mathrm{Kr}$ at near ambient conditions.

\section{Conclusions}

The removal of some volatile radionuclides generated during UNF reprocessing in the US is nearly certain to be necessary for the licensing of a future reprocessing plant in the US and to meet regulatory emission limits.

Various control technologies have been developed, tested, or used over the past 50 years to control volatile radionuclide emissions from UNF reprocessing plants. Some of these control technologies have been used in the past and some are in use today. Caustic scrubbing and adsorption on Agimpregnated or -coated alumina for capturing iodine are in use today in reprocessing plants in France, the United Kingdom, and Japan. Cryogenic distillation has been used for krypton capture at UNF reprocessing plants.

The US DOE has sponsored, since 2009, an Off-Gas Sigma Team to perform research and development focused on the most pressing volatile radionuclide control and immobilization needs. This team has focused mainly on the control and immobilization of ${ }^{85} \mathrm{Kr}$, and ${ }^{129} \mathrm{I}$, because (a) US regulations drive the capture of both ${ }^{129} \mathrm{I}$ and ${ }^{85} \mathrm{Kr}$ based on both a fuel cycle emission rate limit and a dose limit, (b) high control efficiency requirements are expected to drive the development and demonstration of iodine control technologies, and (c) while estimated ${ }^{85} \mathrm{Kr}$ control efficiencies are not as high as control efficiencies estimated for ${ }^{129} \mathrm{I}$ or ${ }^{3} \mathrm{H}$, the cost estimates based on cryogenic noble gas separations technology indicate that considerable cost savings might be possible if alternative krypton capture technologies were available.

Numerous candidate technologies have been researched and developed at laboratory and pilot-plant scales to meet the need for high iodine control efficiency and to advance alternatives to cryogenic separations for krypton control. Some of these show promising results as following.

(i) Iodine decontamination factors as high as $10^{5}$, iodine loading capacities, and other adsorption parameters including adsorption rates have been demonstrated under some conditions for both AgZ and Ag-functionalized aerogel. Studies to convert the spent sorbents into acceptable waste forms are also underway.

(ii) Sorbents including engineered forms of $\mathrm{HZ}, \mathrm{AgZ}$, and selected MOFs have been successfully demonstrated to capture $\mathrm{Kr}$ and $\mathrm{Xe}$ at temperatures close to ambient.

\section{References}

[1] R. T. Jubin, "Summary of FY-12 off-gas sigma team activities," Report No. FCR\&D-SWF-2012-000331, Oak Ridge National Laboratory, 2012.

[2] EPA, Protection of Environment: Chapter I-Environmental Protection Agency (Continued), Part 190 Environmental Radiation Protection Standards for Nuclear Power Operations,
40CFR190.10, US Environmental Protection Agency, Washington, DC, USA, 2010.

[3] NRC, Energy: Part 20-Standards for Protection against Radiation, 10CFR20, chapter 10, US Nuclear Regulatory Commission, Washington, DC, USA, 2012.

[4] NRC, Regulatory Guide 8.37-ALARA Levels for Effluents from Materials Facilities, Nuclear Regulatory Commission, Washington, DC, USA, 1993.

[5] EPA, Environmental Protection Agency: Part 61-National Emission Standards for Hazardous Air Pollutants. Subpart H-National Emission Standards for Emissions of Radionuclides Other than Radon from Department of Energy Facilities, 92-Standard, 40CFR61. 92, chapter 40, US Environmental Protection Agency, Washington, DC, USA, 2010.

[6] R. T. Jubin, B. B. Spencer, and R. M. Counce, "Review of offgas treatment technology relevant to spent nuclear fuel reprocessing," in Proceedings of the Advanced Nuclear Fuel Cycles and Systems International Conference (Global '07), September 2007.

[7] N. Soelberg, M. Abbott, D. Haefner, and R. T. Jubin, "Gaseous fission product emissions control during spent nuclear fuel recycling," in Proceedings of the 235th American Chemical Society National Meeting and Exposition, New Orleans, La, USA, April 2008.

[8] J. E. Kelly, Assessment of the Technical Basis of 40CFR190, Briefing, Sandia National Laboratory, 2009.

[9] R. T. Jubin, N. R. Soelberg, D. M. Strachan, and G. Ilas, "Fuel age impacts on gaseous fission product capture during separations," Report No. FCRD-SWF-2012-000089, Oak Ridge National Laboratory, 2012.

[10] R. Rosnick, CAP-88 (Clean Air Act Assessment Package-1988), US Environmental Protection Agency, Washington, DC, USA, 1992.

[11] R. Rosnick, CAP88-PC Version 3.0 User Guide, Environmental Protection Agency, Washington, DC, USA, 2007.

[12] EPA, "Cancer risk coefficients for environmental exposure to radionuclides," Report No. EPA 402-R-99-001, Environmental Protection Agency, Washington, DC, USA, 1999.

[13] ICRP, "Age-dependent doses to the members of the public from intake of radionuclides-part 5 compilation of ingestion and inhalation coefficients," Report No. ICRP Publication 72, International Commission on Radiological Protection, Ottawa, Canada, 1995.

[14] ASTM, ASTM C833-01, Standard Specification for Sintered Uranium-Plutonium Dioxide Pellets, American Society for Testing and Materials, West Conshohocken, Pa, USA, 2008.

[15] ASTM, ASTM C776-06, Standard Specification for Sintered Uranium Dioxide Pellets, American Society for Testing and Materials, West Conshohocken, Pa, USA, 2011.

[16] H. Wershofen and D. C. Aumann, "Iodine-129 in the environment of a nuclear fuel reprocessing plant: VII. Concentrations and chemical forms of ${ }^{129} \mathrm{I}$ and ${ }^{127} \mathrm{I}$ in the atmosphere," Journal of Environmental Radioactivity, vol. 10, no. 2, pp. 141-156, 1989.

[17] W. Hebel and G. Cottone, "Management modes for iodine-129," in Proceedings of the Commission of the European Communities Meeting, Commission of the European Communities, Brussels, Belgium, 1982.

[18] D. Gombert, R. Counce, A. Cozzi et al., "Global nuclear energy partnership integrated waste management strategy waste treatment baseline study, volume I," Report No. GNEP-WASTAI-RT-2007-000324, Idaho National Laboratory, Idaho Falls, Idaho, USA, 2007. 
[19] IAEA, "Treatment, conditioning and disposal of iodine-129," Report No. Series 276, International Atomic Energy Agency, Vienna, Austria, 1987.

[20] T. Fukusawa, K. Funabashi, and Y. Kondo, "Influences of impurities on iodine removal efficiency of silver alumina adsorbent," in Proceedings of the 24th DOE/NRC Nuclear Air Cleaning and Treatment Conference, CONF-960715, Harvard Air Cleaning Laboratory, Boston, Mass, USA, 1996.

[21] M. Kikuchi, T. Yoshida, M. Matsuda, and H. Kanai, "Developing technologies for nuclear fuel cycles-radioactive waste treatment and spent fuel storage," Hitachi Review, vol. 48, no. 5, pp. 277-284, 1999.

[22] D. R. Haefner and T. J. Tranter, "Methods of gas phase capture of iodine from fuel reprocessing off-gas: a literature survey," Report No. INL/EXT-07-12299, Idaho National Laboratory, Idaho Falls, Idaho, USA, 2007.

[23] K. Funabashi, T. Fukasawa, M. Kikuchi, F. Kawamura, and Y. Kondo, "Development of silver impregnated alumina for iodine separation from off-gas streams," in Proceedings of the 23rd DOE/NRC Nuclear Air Cleaning Conference, CONF-940738, pp. 352-363, Harvard Air Cleaning Laboratory, Boston, Mass, USA, 1994.

[24] T. R. Thomas, B. A. Staples, and L. P. Murphy, “The development of $\mathrm{Ag}^{\circ} \mathrm{Z}$ for bulk ${ }^{129} \mathrm{I}$ removal from nuclear fuel reprocessing plants and $\mathrm{PbX}$ for ${ }^{129}$ I storage," in Proceedings of the 15 th DOE Nuclear Air Cleaning Conference, CONF-780819, p. 394, US Department of Energy, Washington, DC, USA, 1978.

[25] R. T. Jubin, "Organic iodine removal from simulated dissolver off-gas systems using partially exchanged silver mordenite," in Proceedings of the 17th DOE Nuclear Air Cleaning Conference, CONF-820833, pp. 183-196, The Harvard Air Cleaning Laboratory, Boston, Mass, USA, 1982.

[26] R. D. Scheele and L. L. Burger, "Selection of a carbon-14 fixation form," Report No. PNL-4447, Pacific Northwest Laboratory, Richland, Wash, USA, 1982.

[27] K. D. Kok, Ed., Nuclear Engineering Handbook, CRC Press, Boca Raton, Fla, USA, 2009.

[28] M. G. Kanatzidis and S. Bag, "Semiconducting aerogels from chalcogenide clusters wtih broad applications," US Patent No. 2008/0241050 A1, 2008.

[29] J. Lee, O. K. Farha, J. Roberts, K. A. Scheidt, S. T. Nguyen, and J. T. Hupp, "Metal-organic framework materials as catalysts," Chemical Society Reviews, vol. 38, no. 5, pp. 1450-1459, 2009.

[30] J. R. Long and O. M. Yaghi, "The pervasive chemistry of metalorganic frameworks," Chemical Society Reviews, vol. 38, no. 5, pp. 1213-1214, 2009.

[31] G. Férey, C. Serre, T. Devic et al., "Why hybrid porous solids capture greenhouse gases?” Chemical Society Reviews, vol. 40, no. 2, pp. 550-562, 2011.

[32] D. Zhao, D. Q. Yuan, and H. C. Zhou, "The current status of hydrogen storage in metal-organic frameworks," Energy and Environmental Science, vol. 1, no. 2, pp. 222-235, 2008.

[33] H. Furukawa, N. Ko, Y. B. Go et al., "Ultrahigh porosity in metal-organic frameworks," Science, vol. 329, no. 5990, pp. 424428, 2010.

[34] K. Koh, A. G. Wong-Foy, and A. J. Matzger, "A porous coordination copolymer with over $5000 \mathrm{~m}^{2} / \mathrm{g}$ BET surface area," Journal of the American Chemical Society, vol. 131, no. 12, pp. 4184-4185, 2009.

[35] J. R. Li, R. J. Kuppler, and H. C. Zhou, "Selective gas adsorption and separation in metal-organic frameworks," Chemical Society Reviews, vol. 38, no. 5, pp. 1477-1504, 2009.
[36] G. F. Offutt and C. L. Bendixen, "Rare gas recovery facility at the Idaho chemical processing plant," Report No. IN-1221, Idaho Nuclear Corporation, Idaho Falls, Idaho, USA, 1969.

[37] D. T. Pence, "Critical review of noble gas treatment systems," in Proceedings of the 16th DOE Nuclear Air Cleaning Conference, vol. 2 of CONF-80138, pp. 989-1013, The Harvard Air Cleaning Laboratory, Boston, Mass, USA, 1980.

[38] H. Yusa, M. Kikuchi, H. Tsuchiya, O. Kawaguchi, and T. Segawa, "Application of cryogenic distillation to Krypton-85 recovery," Nuclear Engineering and Design, vol. 41, no. 3, pp. 437-441, 1977.

[39] “Treatment of gaseous effluents at nuclear facilities," in Radioactive Waste Management Handbook, W. R. A. Goossens, G. G. Eichholz, and D. W. Tedder, Eds., vol. 2, Harwood Academic Publishers, 1991.

[40] D. K. Little, "Noble gas removal and concentration by combining fluorocarbon absorption and adsorption techniques," in Proceedings of the 17th DOE Nuclear Air Cleaning Conference, CONF-820833, pp. 694-716, US Department of Energy, The Harvard Air Cleaning Laboratory, 1983.

[41] IAEA, “Separation, storage and disposal krypton-85," Technical Report Series No. 199, International Atomic Energy Agency, Vienna, Austria, 1980.

[42] R. W. Glass, P. A. Haas, R. S. Lowrie, and M. E. Whatley, "HTGR head-end processing: a preliminary evaluation of processes for decontaminating burner off-gas," Report No. ORNL-TM-3527, Oak Ridge National Laboratory, Oak Ridge, Tenn, USA, 1972.

[43] R. W. Glass, A. B. Meservey, P. A. Haas et al., "Removal of krypton from the HTGR fuel reprocessing off-gases," ANS Transactions, vol. 15, no. 1, p. 95, 1972.

[44] M. F. Wheatley, "Calculations on the performance of the KALC process," Report No. ORNL-4859, Oak Ridge National Laboratory, Oak Ridge, Tenn, USA, 1973.

[45] D. M. Ruthven, Principles of Adsorption \& Adsorption Processes, John Wiley \& Sons, New York, NY, USA, 1984.

[46] L. E. Trevorrow, G. F. Vandegrift, V. M. Kolba, and M. J. Steindler, "Compatibility of technologies with regulations in the waste management of H-3, I-129, C-14, and Kr-85. Part I. Initial information base," Report No. ANL-83-57, Argonne National Laboratory, Argonne, Ill, USA, 1983.

[47] D. T. Pence, "Critical review of noble gas recovery and treatment systems," Nuclear Safety, vol. 22, no. 6, 1981.

[48] S. H. Bruffey, "Evaluation of iodine and tritium co-adsorption on silver mordenite using neutron scattering," Report No. FCRD-SWF-2012-000257, Oak Ridge National Laboratory, Oak Ridge, Tenn, USA, 2012.

[49] B. B. Spencer, R. T. Jubin, S. H. Bruffey, K. K. Anderson, and J. F. Walker Jr., "Assessment of tritium (water)/iodine coadsorption on AgZ," Report No. FCRD-SWF-2012-000210, Oak Ridge National Laboratory, Oak Ridge, Tenn, USA, 2012.

[50] N. Soelberg and T. Watson, "Iodine sorbent performance in FY, 2012 deep bed tests," Report No. FCRD-SWF-2012-000278, INL/EXT-12-EXT-12-27075, Idaho National Laboratory, Idaho Falls, Idaho, USA, 2012.

[51] S. H. Bruffey, K. K. Anderson, R. T. Jubin, and J. F. Walker Jr., "Aging and iodine loading of silver-functionalized aerogels," Report No. FCRD-SWF-2012-000256, Oak Ridge National Laboratory, Oak Ridge, Tenn, USA, 2012.

[52] S. M. Kuznicki, V. A. Bell, S. Nair et al., "A titanosilicate molecular sieve with adjustable pores for size-selective adsorption of molecules," Nature, vol. 412, no. 6848, pp. 720-724, 2001. 
[53] D. Ianovski, K. Munakata, S. Kanjo et al., "Adsorption of noble gases on H-mordenite," Journal of Nuclear Science and Technology, vol. 39, no. 11, pp. 1213-1218, 2002.

[54] A. Ansón, S. M. Kuznicki, T. Kuznicki et al., "Adsorption of argon, oxygen, and nitrogen on silver exchanged ETS-10 molecular sieve," Microporous and Mesoporous Materials, vol. 109, no. 1-3, pp. 577-580, 2008.

[55] C. A. Fernandez, S. K. Nune, R. K. Motkuri et al., "Synthesis, characterization, and application of metal organic framework nanostructures," Langmuir, vol. 26, no. 24, pp. 18591-18594, 2010.

[56] J. Liu, P. K. Thallapally, and D. M. Strachan, "Metal-organic frameworks for removal of $\mathrm{Xe}$ and $\mathrm{Kr}$ from nuclear fuel reprocessing plants," Langmuir, vol. 28, no. 31, pp. 11584-11589, 2012.

[57] D. W. Breck, Zeolite Molecular Sieves, John Wiley \& Sons, New York, NY, USA, 1974.

[58] K. Munakata, S. Yamatsuki, K. Tanaka, and T. Fukumatsu, "Screening test of adsorbents for recovery of krypton," Journal of Nuclear Science and Technology, vol. 37, no. 1, pp. 84-89, 2000.

[59] K. Munakata, S. Kanjo, S. Yamatsuki, A. Koga, and D. Ianovski, "Adsorption of noble gases on silver-mordenite," Journal of Nuclear Science and Technology, vol. 40, no. 9, pp. 695-697, 2003.

[60] T. G. Garn, J. D. Law, M. R. Greenhalgh, and T. J. Tranter, "A composite media for fluid stream processing, a method of forming the composite media, and a related method of processing a fluid stream," US Patent Application 2939-10703 BA-590, 2012.

[61] T. G. Garn, J. D. Law, and M. R. Greenhalgh, "FY-12 INL krypton capture activities supporting the off-gas sigma team," Report No. FCR\&D-SWF-2012-000252, Idaho National Laboratory, Idaho Falls, Idaho, USA, 2012.

[62] P. K. Thallapally, J. W. Grate, and R. K. Motkuri, "Facile xenon capture and release at room temperature using a metal-organic framework: a comparison with activated charcoal," Chemical Communications, vol. 48, no. 3, pp. 347-349, 2012.

[63] C. A. Fernandez, J. Liu, P. K. Thallapally, and D. M. Strachan, "Switching $\mathrm{Kr} / \mathrm{Xe}$ selectivity with temperature in a metalorganic framework," Journal of the American Chemical Society, vol. 134, no. 22, pp. 9046-9049, 2012. 


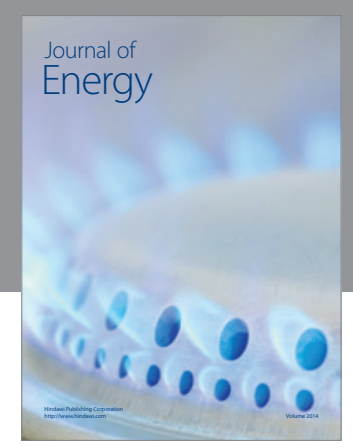

Journal of

Industrial Engineering
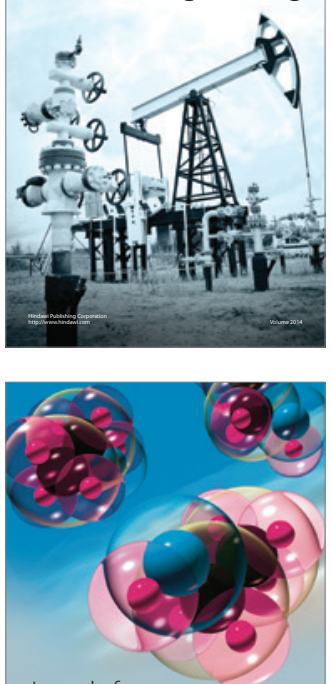

Fuels
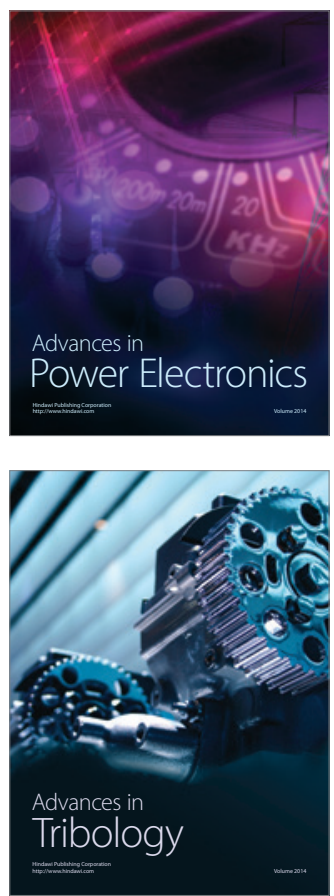

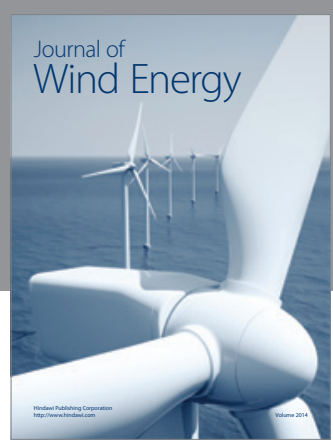

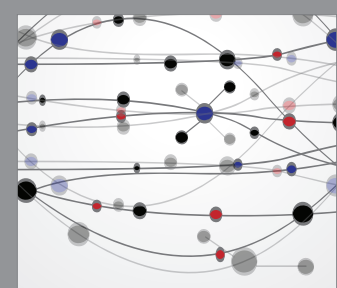

The Scientific World Journal

Submit your manuscripts at http://www.hindawi.com

Journal of

Structures
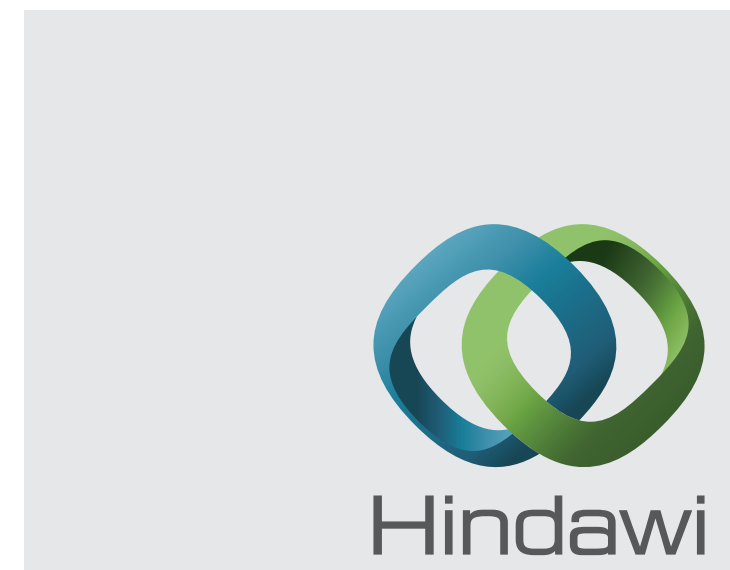

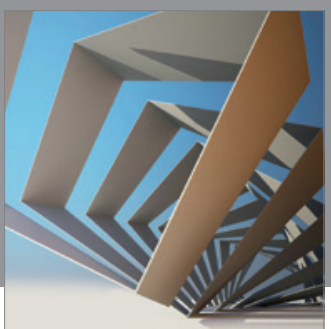

Rotating

Machinery
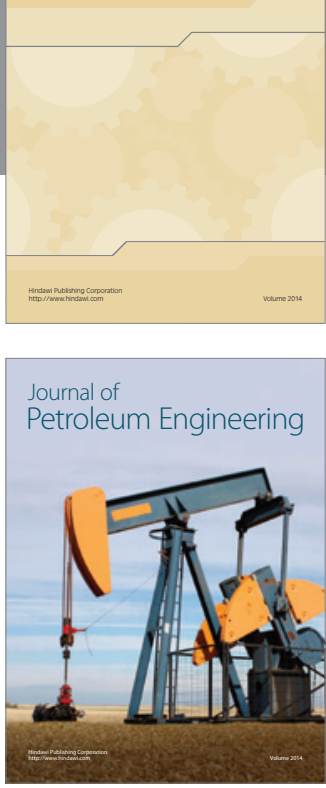

Journal of

Solar Energy
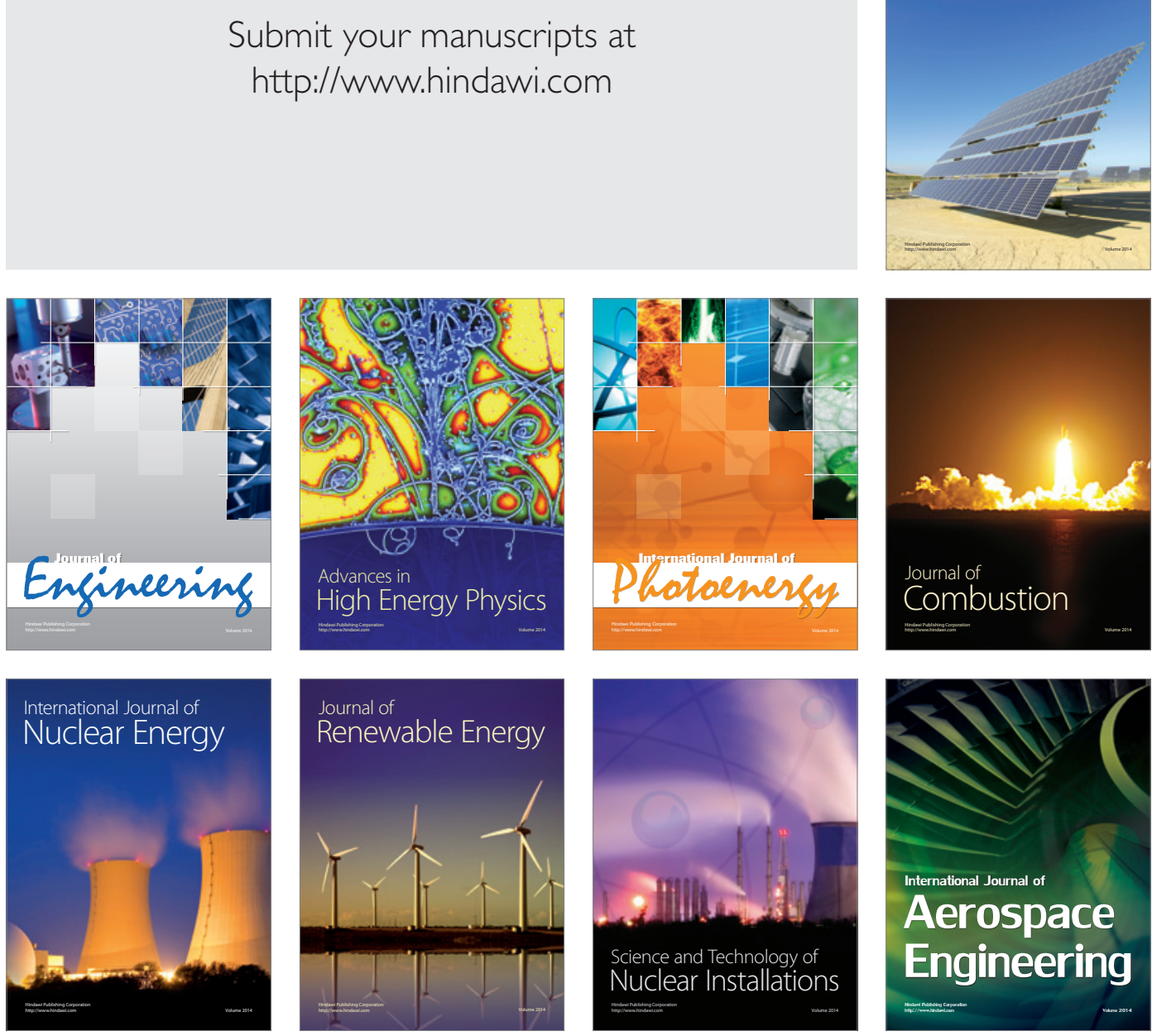